\title{
GLOBALISATION OF FINANCIAL REPORTING STANDARD OF LISTED COMPANIES IN ASEAN TWO: MALAYSIA AND SINGAPORE
}

\author{
Daw Tin Hla \\ Universiti Malaysia Sarawak \\ Abu Hassan bin Md Isa \\ Universiti Malaysia Sarawak
}

\begin{abstract}
Malaysia and Singapore are the top two successful economies in the ASEAN region. They are converging their national accounting standards with the International Financial Reporting Standards (IFRSs) in an attempt to be more globalised. The globalisation of financial reporting standard is not just accounting focus but also for enhancing the quality and transparency of financial reporting of the firms in these countries. Investors and the other stakeholders rely on financial information reported by the firms on their websites to enable the information to access globally. This study focuses on the globalisation of financial reporting standards, corporate governance and transparency practice by the firms listed on Bursa Malaysia and Singapore. It is to analyse the level of financial reporting quality of the firms in compliance with the International Financial Reporting Standards (IFRS) in their annual reports by using disclosure analysis. Additionally, it determines the association between the financial reporting quality with IFRS compliance, and corporate governance and transparency practice of the firms listed on the main markets of Bursa Malaysia and main board of Singapore Stock Exchange (SGX), using multiple regression analysis. The finding of this study highlights the association of higher level of financial reporting quality with IFRS compliance of the firms, and their good corporate governance and transparency practice are positively associated in these two countries. This study also provides some opportunities to achieve sustainable convergence with the International Financial Reporting Standards of the firms by improving corporate governance and transparency in ASEAN countries.
\end{abstract}

Keywords: International Financial Reporting Standards; Corporate Governance; Transparency and Disclosure Practice; Malaysia and Singapore.

2 Corresponding Author: Daw Tin Hla, Senior Lecturer, Department of Accounting and Finance, Universiti Malaysia Sarawak (UNIMAS), 94300 Kota Samarahan, Sarawak, Malaysia, Phone: 6082 584409, Fax: 6082-583999, E-mail: thdaw@ feb.unimas.my. 


\section{INTRODUCTION}

The epistemology of this study is that there might be an association between the adherence of financial reporting quality with the International Financial Reporting Standards of a firm and its good corporate governance and transparency practices based on the agency theory. Financial reporting globalisation is commonly popular among the countries where more than one hundred countries around the world have been converging their national standards with the International Financial Reporting Standards (IFRS) since in early the year of 2000s. The reason of the converging is to be globalised and to provide reliable and transparent financial information to the stakeholders. Agency problem may arise because of the inefficiencies and the lack of sufficient information disclosed in annual reports. The higher level of financial reporting quality with the International Financial Reporting Standards may provide higher quality information where good corporate governance and transparent practice are reflected in transparency information should be disclosed in financial reports to deliver constructive environment for investors in the capital markets. It also concerns that the other supportive circumstances such as an International level of auditing as an accreditation of their annual reports, earlier adoption of the IFRS might provide more experience for being higher level of IFRS compliance; higher competition in the market might demand higher level of financial reporting quality and foreigner shareholders composed in the ownership of the firm might demand higher level of financial reporting quality with IFRS compliance.

The main objective of this study is to evaluate the level of financial reporting quality with IFRS compliance by the listed companies in Malaysia and Singapore, and to compare the level of financial reporting standard with IFRS compliance. And the other objectives are to determine the associations between the level of financial reporting standards with IFRS compliance and corporate governance and transparency practices of the firms in these two countries.

\section{LITURE REVIEW}

\subsection{Financial Reporting Quality and Corporate Governance}

Corporate governance assists in the strengthening of the overall international financial reporting standard and reduces the vulnerability of emerging markets to financial crisis. Prior corporate governance researches in accounting investigated the properties of accounting system and the surrounding institutional environmental importance to the effective governance of the firms (Bushman and Smith, 2001). The extension of the study conducted by McGee (2008) considered the corporate transparency more generally, which included financial accounting information as one of the elements of a complex infrastructure. They deliberated on the usefulness of financial accounting information as an incentive contract of top management in corporate governance mechanism. DeAngelo (1981) suggested that accounting information may better reflect incumbent managerial performance.

The World Bank (2005) conducted a number of studies on corporate governance practices of various countries all over the world. Accessing corporate governance practice based on the OECD principles and their observance levels on each category of corporate governance 
practices (McGee, 2008). The study included eight Asian countries; noticeably excluded ones are China, Japan and Singapore. None of the countries had perfect score of 110 given $(100 \%)$. India came closest with a percentage score of $83.6 \%$, followed closely by Malaysia $(77.3 \%)$. Chuanrommanee et al. (2007) documented the progresses in corporate governance through the analysis of the corporate websites of financial corporations in these countries; and they found that corporate governance practices of Malaysian and Singapore financial corporations are consistent with international best practices.

The Cadbury Report (1992) published the findings of the Committee on Financial Aspects of Corporate Governance. It has separated sections on the principles of corporate governance, the role of directors, directors' remuneration, the role of shareholders, accountability, audit issued conclusions and recommendations. The OECD's Principles of Corporate Governance $(1999)^{1}$ has used as a benchmark for a number of corporate governance codes in transition economies. The OECD has also published several studies on corporate governance in Asia; the most notable being was its White Paper on Corporate Governance in Asia (2003). Clarke (2000) studied on corporate governance focused on the Asian financial crisis; stated that it was partially caused by poor corporate governance practices.

The association of South East Asian Nations (ASEAN) has been established since 8 August 1967 in Bangkok by five founder member countries: Indonesia, Malaysia, Philippines, Singapore and Thailand. Brunei Darussalam joined in 1984, Vietnam in 1995, Laos and Myanmar (Burma) in 1997, and Cambodia in 1999. Among ASEAN founder five countries, Singapore capital market and Malaysia capital market are leading the stock markets in the ASEAN region. In Malaysia, the Securities Commission together with other government agencies and the industry revised the code to bring the country's corporate governance framework more in line with currently globally accepted best practices. The code came into effect on October 1 , 2007. The key amendments aimed at strengthening the roles and responsibilities of the boards of directors and audit committees, and ensuring the discharge their duties effectively. The eligibility criteria for the appointment of directors, the composition of the board of directors and the role of the nominating committee, are clearly outlined. Brown and Caylor (2004) used corporate governance score, composite measures of 52 factors encompassing eight governance categories, and five measures of performances. They found that better governed firms are more profitable, more valuable, less risky, less volatile, and pay out more cash to their shareholders.

\subsection{Accounting Standard Validation by the International Auditors}

Convergence of accounting standard with IFRS spearheaded significant progress in the convergence of audit standards and the development of global audit standards within the next decade (Lopez, 2009). The International Federation of Accountants (IFAC) and its board, the International Auditing and Assurance Standards Board (IAASB), issue auditing standards through a public process. Many global auditing organisations incorporate the International Standards on Auditing (IAS) into their global audit policies and programmes.

Organisation for Economic Co-operation and Development, OECD principles of corporate Governance, available at www.oecd. org/dataoecd/32/18/31557724.pdf 
Within the extent literature on the subject, it has been a common issue to view audit firm size as a surrogate for audit quality. It has often been assumed that larger audit firms incur costs to develop a reputation for adding value to the audit and are better able to detect and reveal management's errors or irregularities in financial reporting (DeFond and Jiambalvo, 1993). DeAngelo (1981) stated that large auditors have more reason to issue accurate reports because they have more valuable reputations. Fuerman (2006) exposed evidence which might point to a conclusion of quality differentiation between Big-6 auditors. The results of that study suggested that Coopers \& Lybrand, Deloitte \& Touche Tohmatsu, Ernst \& Young, KPMG and Price Waterhousecooper each produced higher quality audit compared to non-Big-4 audit firms. Khurana and Raman (2004) investigated whether reputation concerns could cause Big-4 auditors/audit firms to provide higher quality audit than non-Big-4 firms in ASEAN countries where litigation exposure is low or non-existent. They use quality of reported earnings as a proxy for audit quality. Their findings highlighted that the quality of Big-4 audit and non-Big-4 audit firms in ASEAN are not significantly different in the period; it was before IFRS adoption period (1990-1996). It suggests this current study to investigate whether the international audit quality (Big-4 audit firms) is an important determinant of financial reporting quality with the level of higher IFRS compliance after adopting IFRS broadly in Malaysia and Singapore.

\subsection{Transparency and Disclosure Practice}

Healy and Palepu (2001) pointed out that, through financial reporting with information disclosures, companies could have lower information asymmetry and agency conflicts between management and external investors. Ho and Wong (2001) concluded that increasing information disclosures in annual reports may reduce information asymmetry, improve management performance, save cost in terms of the investor's privately produced information, and enhance corporate image. It also satisfies the needs of information users and achieves the goal of lowering the company's investment costs. Gelb and Zarowin (2002) proposed that the information transparency improves the values of shares. Daske and Günther (2006) examined the quality of financial statements of Australian, German and Swiss firms that had already adopted the IFRS. They provided evidence that disclosure quality increased significantly under IFRS adoption in the European countries, for which voluntarily adopted IFRS, as well as for firms, which mandatorily adopted such standards in response to the requirements of specific stock markets segments. In an Australian context, beyond exploring the impact of IFRS adoption on financial statements, Jones and Higgins (2006) explored the perceptions of senior finance personnel from Australia's Top 200 companies towards the quality of IFRS. The IFRS adoption would either improves the quality of financial reports or that IFRS are more transparent and understandable in comparison with existing Australian Accounting Standard Board (AASB) standards.

According to the prior study in Asia, publicly listed companies in South Asian countries are still grappling with the problem of low information transparency (World Bank, 1998 and The Asian Wall Street Journal, 1999). Converging of local accounting standards with international financial reporting standards, transparency and disclosure requirements are to be improved in the securities market. Daske et al. (2008) presented that IFRS adoption will lead to improved transparency and higher quality financial reporting, which is effectively improving firm information environment. 
Lin, et al. (2007) examined the association between the level of transparency and informative accounting earnings. They measured the information transparency by using "Information Transparency and Disclosure Ranking System (ITDRS)" to assess the information transparency and disclosure practices of 88 listed companies in Taiwan. Their empirical results moderate that information transparency is positively associated with the informative accounting earning.

\section{RESEARCH METHODOLOGY}

\subsection{Analysis of Financial Reporting Quality with the Level of IFRS Compliance}

The methodology of this study applies empirical analyses to test the hypotheses by using multiple regression accounting models to achieve the objectives of this study. Firstly, disclosure content analysis is applied to assess the level of financial reporting quality with IFRS compliance by the non-financial corporations listed on main market of Bursa Malaysia and main board of SGX. Secondly, it tests the hypotheses by using multiple regression analysis with mitigating the limitations of the analysis, that is, to determine the good corporate governance and transparency practice that can claim the firms' financial reporting quality with the level of higher IFRS compliance in these two countries.

The data analysis was based on a sample size of 160 companies from each country, systematic random sampling is used to get the required sample size from the different sectors of the main markets in each country. The final sample size reached 158 firms for Malaysia and 159 firms for Singapore. Content analysis was employed to examine the financial reporting disclosures based on the fourteen IFRS commonly disclosed in an annual report of a firm. The disclosure requirements of fourteen IFRS standards which include property plant and equipment, business combination, tangible assets, impairment of assets, stock and long term contracts, deferred tax, leases, retirement benefits, marketable securities, research and development expenditure, revenue recognition, contingent liabilities and contingent assets, segmental reporting, and related party disclosure. Validity and reliability of measuring the higher level of IFRS compliance, content analysis program is constructed by setting queries on key disclosure requirements (mandatory disclosure requirements) of each and every fourteen IFRS standard in the QSR NVivo 9 (Qualitative Data Analysis). The annual reports of the firms were saved in the input unit and a standard format of annual report issued by the International Accounting Standard Board (IASB, 2008) was stored in the memory storage area of the software. Queries to find the relevance disclosures of selected fourteen IFRSs were set up in the software to examine the contents of disclosure requirements included in annual report of an individual firm. Then, the total compliance percentages of the fourteen IFRS were computed as a percentage of the highest score possible for each firm.

The following equation describes the mathematic formula to calculate the weighted average of the fourteen IFRS compliance scores of a firm, the similar method of calculation was also applied by Street and Gray (2002) and Al-Shiab (2008) in their studies.

$$
F R Q_{i}=\frac{\sum_{j=1}^{14} X_{j}}{S_{i}}
$$


Where $X j$ refers compliance score of a single IFRS, $j$ is from one to fourteen items of IFRS standards; $F R Q$ is the level of the total IFRS compliance of i firm, $0 \leq F R Q_{i t} \leq 1$. Each level of compliance with one item of IFRS standard, mandatory disclosure requirement for firm $i$ is $\mathrm{Xj}$. The total number of applicable IFRS standards for a firm $\left(S_{i}\right)$ divided by the sum of these compliance scores for each company. This calculation method gives unequal weighting to the disclosure items in different IFRS standards. Different firms might imply different scores for each IFRS in their annual reports. The result of the content analysis provides a data set of the level of IFRS compliance of the firms.

The main objective of this study is to evaluate the level of financial reporting quality with IFRS compliance by the listed companies in Malaysia and Singapore. It is hypothesized that the non-financial corporation listed on Bursa Malaysia and SGX are implementing financial reporting quality with the level of higher IFRS compliance to converge in globalisation. It is also hypothesised that the financial reporting quality of firms in the main market of Bursa Malaysia and in the SGX main board highly complies with the International Financial Reporting Standards (IFRs).

Two samples t test was used to analyse the mean value of financial reporting quality with the level of higher IFRS compliance scores of firms in these two countries. The data analysis conducted was based on the dataset of financial reporting quality with the level of compliance measured by content analysis. Regarding the content analysis of financial reporting quality with the level of higher IFRS compliance, the level of IFRS compliance percentage of at least 60 per cent defined as higher IFRS compliance; otherwise, it was determined as lower level of IFRS compliance.

Data analysis was applied to the financial reporting quality of IFRS compliance dataset of 158 companies with 14 IFRS standards measures and reaches 2212 of the total observations. The result of the analysis of Bursa Malaysia shows that the t-statistic (23.07) is positively significant at the $1 \%$ level (Table 1); thus, this provides the significant evidence to conclude that the financial reporting quality with the level of higher IFRS compliance positively differ from mean value of IFRS compliance $(60 \%)$. This suggests that the financial reporting quality of non-financial corporations listed on the main market of Bursa Malaysia highly comply with IFRS, and the firms have implemented the financial reporting quality with the level of higher IFRS compliance in their annual reports. The result of SGX reveals that the t-statistic (6.24) is significantly positive at the $1 \%$ level (see Table 1); The findings provide the significant evidence to conclude that non-financial corporations listed on Bursa Malaysia and SGX are implementing the higher level of financial reporting quality with the level of higher IFRS compliance.

Comparing two cases, the result of t-statistic for the financial reporting quality results in Bursa Malaysia is 3 times larger than the results of SGX. The non-financial corporations listed on main market of Bursa Malaysia are implementing IFRS that is identical to the IFRS formats of financial reports issued by IASB, so the result is slightly higher than the firms listed on main board of SGX. The firms listed on main board of SGX are implementing IFRS that are not identical to IFRS of IASB; some annual reports presented in the format of US GAAP and some annual reports are Chinese national financial reporting formats. 


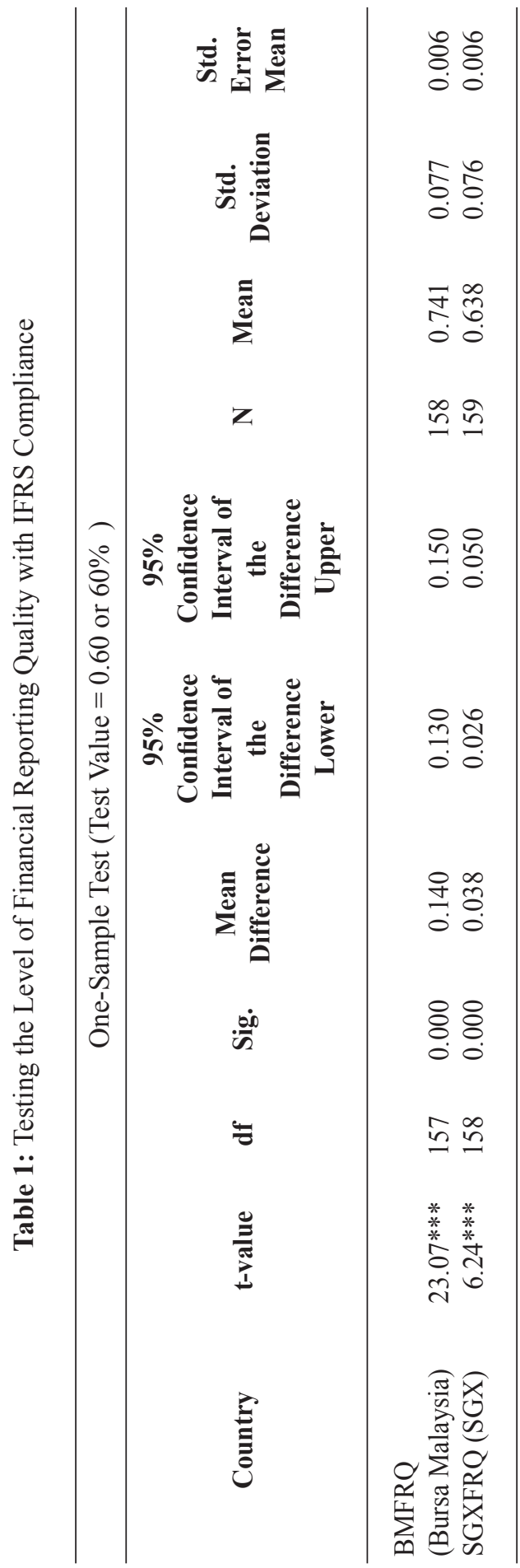




\subsection{Financial Reporting Quality and Its Determinants}

Tilis (2005) supported that the preponderance of views within the audit quality literature. Among the view were that the quality of audits undertaken by large firms exceeds that of audits carried out by smaller firms and there is little evidence strongly supportive of quality differentials among the large audit firms. These findings propose that the international audit firms are more strongly supportive of quality assurance of the firms' accounting to comply with IFRS than the local audit firms. This study expects that if a firm uses any one of the Big4 audit firms as their external auditor that may be positively associated with their financial reporting quality with a higher level of compliance with IFRS than using local audit firms.

Raghavan et al. (2010) and Beeks (2006) examined the contention that a strengthening of corporate governance mechanisms would result in the improved relevance and reliability of financial statements. They found the positive and significant relationship between corporate governance and earnings quality and the role of executive compensation. Stent and Bradbury (2010) indicated that there was likely to be a link between good corporate governance and disclosures in annual reports to draw attention of users to the international financial reporting information. Regarding their findings, this study expects that the higher level of financial reporting quality with IFRS compliance and good corporate governance practice may be positively associated. Additionally, the objective of this study aims to analyse the determinants that can predict the financial reporting quality with IFRS compliance. It is hypothesised that financial reporting quality with IFRS can be significantly determined by using the international audit firms (Big-4 audit firms), good corporate governance practice and transparency and disclosure practice in Malaysia and Singapore.

Testing of these hypotheses employs the following financial reporting quality with IFRS compliance models:

The model of financial reporting quality with IFRS compliance for Malaysia and Singapore is:

$$
\begin{aligned}
& F R Q_{i t}=\alpha_{1}+\beta_{1} \text { EarlyIFRS }_{i t}+\beta_{2} \text { Audit }_{i t}+ \\
& \beta_{3} \text { CorGov }_{i t}+\beta_{4} \text { Trans \& }_{\text {Dis }}+\beta_{5} \text { Comp }_{i t}+\beta_{6} \text { Owner }_{i t}+\varepsilon_{1 i t}
\end{aligned}
$$

In the above multiple regression Models, $\alpha_{1}$ is the intercept of Model $2 ; \beta_{1}, \beta_{2}, \beta_{3}, \beta_{4}, \beta_{5}$ and $\beta_{6}$. are partial correlation coefficients of the respective independent variables; $\varepsilon_{1 i t}$ is a random error for the Model 1 and 2 respectively. The abbreviation, $F R Q_{i t}$ means financial reporting quality with IFRS compliance of firm $i$ at time $t$. These financial reporting quality with IFRS compliance are dependent variables in the model and the independent variables are: EarlyIFRS, earlier adoption of IFRS by the firms; AuditQ interprets audit quality of using the international audit firm (Big-4 audit firms); CorGov is corporate governance practice; Trans \& Dis is transparent and disclosure practice; Comp is the proxy for competition of the firms in the equity market based on the number of firms trading in the same sector of market; and Owner is the proxy for ownership either foreigners or local shareholders in the board of directors of a firm. These are the proxies for the determinants of financial reporting quality with IFRS compliance in both countries. 
The analysis in this study ensures to meet the basic assumptions of regression analysis to exclude any serious violations of the assumptions by involving two steps: (1) testing the individual dependent and independent variables, and (2) testing the overall relationship before the model estimations. The three assumptions are addressed to account for the individual variables are linearity, constant variance, and normality of the distribution data set. For purpose of the regression analysis, firstly examination of dependent and independent variables by using scatter plots of the individual variables, the results do not indicate any nonlinear relationship between the dependent and the independent variables in this analysis. Spearman correlation is applied to confirm whether there is multicollinearity effect among the independent variables that can cause strange results when attempting to study how well individual independent variable determines the dependent variable. Spearman correlation test indicates that there is no multicollinearity among the independent variables which are not closely correlated to one another. All independent variables have their variance inflation factors (VIF) are less than 4 in both data sets of Bursa Malaysia and SGX. Therefore, the accounting quality models are statically suggested that there is no multicollinearity effect among the variables of Bursa Malaysia and SGX to predict the associations between the dependent and independent variables.

\section{FINDING AND CONCLUSION}

Table 2 shows the results of regression analysis for Bursa Malaysia and SGX, by using financial reporting quality with the level of higher IFRS compliance and it determinant models (Model 2). Financial reporting quality with IFRS compliance positively regresses on the firms' good corporate governance practice and transparent with disclosure practices in both countries. These findings are consistently and highly significant at 1 per cent level in both Malaysia and Singapore. However, the earlier adoption of IFRS is significant at 5 per cent in Malaysia and it is at 1 per cent in Singapore. The importance of the international audit quality in Singapore is more significant than the audit quality in Malaysia.

In general, the main conclusion that can be drawn from this study is that a firm's financial reporting quality with the level of higher IFRS compliance could be expected to increase when the firm early adopts IFRS, has good corporate governance practice in accounting and transparent disclosure practices, holding the other independent variables constant. The financial reporting quality with the level of higher IFRS compliance is positively associated with good corporate governance practice and transparent and disclosure practice in Malaysia and Singapore. Malaysia firm's financial reporting quality with IFRS compliance does not rely on the international audit firms; and early adoption of IFRS could deliver the financial reporting quality with higher IFRS compliance, good corporate governance practice and transparency practice are significant to be higher level of IFRS compliance in financial reporting of firms in Malaysia. The finding of good corporate governance practice is also consistent with the findings of World Bank corporate governance analysis regional survey on Malaysia (World Bank, 2006). However, the regression coefficient of Trans \& Dis in Singapore is slightly higher than Malaysia that can be interpreted, as the financial reporting of non-financial corporations in SGX is supposed to be more transparency than that Bursa Malaysia firms. Financial reporting quality with IFRS compliance of the firms from SGX significantly relies on the international audit firms. 
The outcomes of this study contribute useful information to both national and international accounting standard setters such as the International Accounting Standards Board, the International Financial Reporting Committee, and the capital markets' participants. This study also provides the information about the situation of IFRS implementation by the firms and convergence status of their national accounting standards with the IFRS for the achievement of globalisation in financial reporting system. Improving transparency and disclosure practice in financial reporting can offer investors more reliable financial information as an important contribution of the study on accounting and equity capital markets in Malaysia and Singapore. It will also provide reliable information for the international businesses which are looking forward investing in Malaysia and Singapore; eventually promote the national economy of these countries.

Table 2: Regression Results of Financial reporting quality Model

\begin{tabular}{cccccc}
\hline \multicolumn{2}{c}{ ANOVA RESULTS } & \multicolumn{2}{c}{$\begin{array}{c}\text { Financial Reporting of firms } \\
\text { on Bursa Malaysia }\end{array}$} & \multicolumn{2}{c}{$\begin{array}{c}\text { Financial Reporting of } \\
\text { firms on SGX }\end{array}$} \\
\hline Variables & $\begin{array}{c}\text { Expected } \\
\text { Sign }\end{array}$ & $\begin{array}{c}\text { Standardized } \\
\text { Coefficients }\end{array}$ & t-value & $\begin{array}{c}\text { Standardized } \\
\text { Coefficients }\end{array}$ & t-value \\
\hline Constant & & 0.425 & 18.854 & 0.307 & 15.218 \\
EarlyIFRS & + & $0.019 * *$ & 2.354 & $0.077 * * *$ & 3.559 \\
AuditQ & + & 0.0001 & 0.697 & $0.019 * * *$ & 2.764 \\
CorGov & + & $0.042^{* * *}$ & 13.033 & $0.134 * * *$ & 5.494 \\
Trans\&Dis & + & $0.094^{* * *}$ & 5.324 & $0.178^{* * *}$ & 4.31 \\
Comp & + & -0.001 & 0.069 & 0.057 & 0.722 \\
Owner & + & -0.009 & -0.821 & 0.005 & 0.814 \\
N & & & 158 & & 159 \\
R & & & 0.931 & & 0.893 \\
R squared & & & 0.867 & & 0.798 \\
Durbin-Watson Test & & & 2.123 & & 2.022 \\
F Statistics & & & 164.69 & & .000 \\
p-value & & & .000 & & \\
\hline
\end{tabular}

Notes: *** Significant at the $1 \%$, ** significant at the $5 \%$, and $*$ Significant at $10 \%$. These financial reporting quality with IFRS compliance are dependent variables in the model and the independent variables are: EarlyIFRS, earlier adoption of IFRS by the firms; AuditQ interprets audit quality of using the international audit firm (Big-4 audit firms); CorGov is corporate governance practice; Trans \& Dis is transparent and disclosure practice; Comp is the proxy for competition of the firms in the equity market based on the number of firms trading in the same sector of market; and Owner is the proxy for ownership either foreigners or local shareholders in the board of directors of a firm.

\section{ACKNOWLEDGEMENT}

The authors acknowledge the financial support rendered by Universiti Malaysia Sarawak (UNIMAS) through the Fundamental Research Grant No. FRGS/05(27)781/2009(62). 


\section{REFERENCES}

Al-Shiab, M. (2008). The effectiveness of International Financial Reporting Standards adoption on cost of equity capital: A vector error correction model. International Journal of Business, 13(3), 271-298.

Beeks, W., \& Brown, P. (2006). Do better governed Australian firms make more informative disclosures. Journal of Business Finance and Accounting, 33(3-4), 422-450.

Brown, L. D., \& Caylor, M. L. (2004). Corporate governance and firm performance. Georgia State University Working paper.

Bushman, R., \& Smith, A. (2001). Financial accounting information and corporate governance. Journal of Accounting and Economics, 32(3), 237-333.

Chuanrommanee, W., \& Swierczek, F. W. (2007). Corporate governance in ASEAN financial corporations: reality or illusion? Corporate Governance, An International Review, $15(2), 272-283$.

Clarke, T. (2000). The Power of international financial markets and the weaknesses of Asian modes of corporate governance. Corporate Governance, 8(2), 101-116.

Daske, H., \& Günther, G. (2006). International Financial Reporting Standards and experts' perceptions of disclosure quality. A Journal of Accounting, Finance and Business Studies, 42 (3-4), 461-498.

Daske, H., Hail, L., Leuz, Ch., \& Verdi, R. (2008). Mandatory IFRS reporting around the world: early evidence on the economic consequences. Journal of Accounting Research, 46(5), 1085-1142.

DeAngelo, L. E. (1981). Auditor size and auditor quality. Journal of Accounting and Economics, 3(3), 183-199.

DeFond, M, \& Jiambalvo, J. (1993). Factors related to auditor-client disagreement over income-increasing accounting methods. Contemporary Accounting Research, 9(2), 415 431.

Fuerman, R. D. (2006). Comparing the auditor quality of Arthur Andersen to that of the Big 4. Accounting and the Public Interest, 6(1), 135-161.

Gelb, D. S., Zarowin, P. (2002). Corporate disclosure policy and the in formativeness of stock price. Review of Accounting Studies, 7(1), 33-53.

Healy, P. M., \& .Palepu, K. G. (2001). Information asymmetry, corporate disclosure, and the capital markets: A review of the empirical disclosure literature. Journal of Accounting and Economics, 31(1-3), 405-440.

Ho, S. S. M., \& Wong, K. S. (2001). A study of the relationship between corporate governance structures and the extent of voluntary disclosure. Journal of International Accounting, Auditing \& Taxation, 10(2), 139-156. 
IASB. (2008). Model of IFRS Financial Reports 2008. United Kingdom: IASC Foundation.

Jones, S., \& Higgins, A. D. (2006). Australia's switch to international financial reporting standards: a perspective from account prepares. Accounting and Finance, 46(4), 629652 .

Khurana, I. K., \& Raman, K. K. (2004). Are Big Four audits in ASEAN of higher quality than non-Big Four audits? Asia Pacific Journal of Accounting and Economics, 11(2), 201214.

Lin, Y. C., Huang, S. Y., Chang, Y. F., \& Tseng, C. H. (2007). The Relationship between information transparency and the in formativeness of accounting earnings. The Journal of Applied Business Research, 23(3), 23-32.

Lopez, J. T. (2009). Investors' perception of an auditor's adverse internal control opinion. Journal of Accounting and Public Policy, 28(3), 231-250.

McGee, R. W. (2008). Corporate government in Asia: eight case studies. School of Accounting, Collage of Business Administration, Florida International University, Working Paper January 2008.

Raghavan, J., Iyengar, J. L., \& Zampelli, E. M. (2010). Does board of governance improve quality of accounting earnings? Accounting Research Journal, 23(1), 49-68.

Stent, W., Bradbury, M., \& Hooks, J. (2010). IFRS in New Zealand: effects on financial statements and ratios. Pacific Accounting Review, 22(2), 92-107

Street, D. L., \& Gray, S. J. (2002). Factors influencing the extent of corporate compliance with International Accounting Standards: A summary of a research monograph. Journal of International Accounting, Auditing \& Taxation, 11(1), 51-76.

The Asian Wall Street. (1999). Atlantic Financial News. Retrieved December 30, 2014, from http://www.atlanticfinancial.com/about-atlantic-financial/news/Asian_Wall_Street_ Journal.

The Cadbury Report. (1992). Report of the Committee on Financial Aspects of Corporate Governance. London: Gee Publishing Ltd.

Tilis, L. B. (2005). Audit quality and risk differences among auditors. ICFAI Journal of Audit Practice, July, 42-68.

World Bank and International Monetary Fund (June 2005). Report on the observance of Standards and Codes (ROSC), Corporate Governance Country Assessment: Malaysia. Washington, DC

World Bank. (1998). World Bank and International Monetary Fund, East Asia: the road to recovery. Washington DC: World Bank.

World Bank. (2006). Report on the Observance of Standards and Codes (ROSC), Corporate Governance Country Assessment: Malaysia. Washington, DC: World Bank \& IMF. 